\title{
Pengembangan bahan ajar perbandingan berbalik nilai berbasis android untuk pembelajaran sekolah menengah pertama kelas VII
}

\author{
Nuraini, Somakim, Hapizah \\ Program Studi Pendidikan Matematika, Fakultas Keguruan dan Ilmu Pendidikan, \\ Universitas Sriwijaya, Sumatera Selatan, Indonesia \\ E-mail:nainun001@gmail.com
}

\begin{abstract}
ABSTRAK
Penelitian ini dilatarbelakangi karena belum tersedianya bahan ajar berbasis android pada mata pelajaran matematika khususnya untuk materi perbandingan berbalik nilai. Oleh karena itu dilakukan penelitian pengembangan bahan ajar berbasis android yang bertujuan untuk menghasilkan bahan ajar materi perbandingan berbalik nilai berbasis android yang valid dan praktis. Penelitian ini adalah penelitian pengembangan menggunakan model pengembangan ADDIE . Data penelitian ini diperoleh melalui hasil walktrough, lembar angket, dan observasi. Hasil dari penelitian ini menunjukkan bahwa validasi bahan ajar perbandingan berbalik nilai berbasis android yang dilihat dari aspek isi, konstruk, dan bahasa yang dinilai dari hasil validasi ahli materi dan ahli media serta komentar siswa pada saat uji coba perorangan. Sedangkan kepraktisan bahan ajar perbandingan berbalik nilai berbasis android terlihat dari hasil lembar penilaian angket dan observasi pada tahap uji coba kelompok kecil. Dari hasil penilaian angket dan observasi diperoleh perhitungan nilai sebesar 82,17 \% berkategori praktis dan 89,17\% berkategori sangat praktis. Kesimpulan dari penelitian ini adalah bahan ajar perbandingan berbalik nilai berbasis android telah valid dan praktis.
\end{abstract}

Kata Kunci: Pengembangan; Bahan Ajar; ADDIE

\begin{abstract}
The research is facing a background because there is not a more-based teaching material available in mathematical subjects especially for materials of comparative value. And so it is done to rsearch the development of lame-based teaching materials aimed at producing materials that actually contras valid and practical android value. This research is development research using ADDIE development models. These research data are obtained walkthrough, routing sheets, and observations. The results of this study show that the validation of materials rebased android contrasts is seen in content, constructive, andlanguage aspects assessed by both material and media experts validation and student comments during individual trials. The bare-based comparison of value-based values can be seen from the result of the top-rated assessment sheet and the observation at the trial stage of a small group. Based on the value assessments and observations, the rating is $82.17 \%$ practical valise and $89.17 \%$ valegori are extremely practical. The conclusion of this research is that the reverent-based android ratio is valid and practical.
\end{abstract}

Keywords: Development; Teaching Materials; ADDIE

\section{PENDAHULUAN}

Permendikbud Nomor 65 Tahun 2013 Tentang Standar Proses Pendidikan Dasar dan Menengah, disebutkan bahwa salah satu prinsip pembelajaran yang digunakan pada kurikulum 2013 yaitu pemanfaatan Teknologi Informasi dan Komunikasi (TIK) untuk meningkatkan efisiensi dan efektifitas pembelajaran. Terlebih lagi saat ini tengah berkembang revolusi industri 4.0 yang ditandai dengan berkembangnya Internet of Things (IoT) dan diikuti teknologi baru dalam data sains, kecerdasan buatan, robotic, teknologi nano, cetak tiga dimensi dan cloud (Schwab, 2016). Dengan adanya revolusi 4.0 ini banyak munculnya inovasi-inovasi baru dalam berbagai bidang kehidupan manusia terlebih lagi dalam penggunaan alat komunikasi seperti smartphone android. 
Berdasarkan Statista (2019), jumlah pengguna smartphone diseluruh dunia terus tumbuh dari 1,57 milyar pada tahun 2014 menjadi 2,71 milyar pada tahun 2019 dan diperkirakan akan terus berkembang menjadi sekitar 2,87 milyar pada tahun 2020. Negara Indonesia menempati urutan ke-empat pengguna aktif smartphone didunia setelah Cina, India, dan Amerika (Novalius, 2018). Berdasarkan karakteristik usia, smartphone tidak hanya digunakan oleh orang dewasa namun juga oleh remaja dan anak-anak usia sekolah. Dilihat dari hasil statistik di Indonesia pengguna smartphone dikalangan anak-anak mencapai angka 132,7 juta (APJII, 2015). Fasilitas yang menarik dan fitur smartphone yang semakin maju dan berkembang telah menarik perhatian siswa untuk semakin sering menggunakan smartphone (Widadi, \& Pramudita, 2018). Seharusnya hal ini juga dapat menarik perhatian siswa untuk memanfaatkan smartphone android dalam pembelajaran.

Namun pada kenyataannya tidak sedikit siswa yang menggunakan android untuk hal-hal yang tidak bermanfaat seperti bermain game, update status di sosial media dan sebagainya. Jika tidak diperhatikan hal ini akan menimbulkan dampak negatif bagi siswa. Yuni dan Pierewan (2019) menemukan kecenderungan semakin tinggi intensitas penggunaan android dalam hal negatif maka semakin rendah disiplin belajar siswa. Dengan kata lain siswa akan menjadi malas belajar karena kecanduan dalam menggunakan android. Pada kasus ini dibutuhkan peranan orang tua untuk lebih memperhatikan anaknya pada saat menggunakan android di rumah. Orang tua harus mampu mengontrol anaknya agar menggunakan android dengan bijak.

Selain orang tua, untuk menyelesaikan masalah tersebut dibutuhkan juga peran guru dalam proses pembelajaran. Pada mata pelajaran matematika, mayoritas siswa mengalami kesulitan baik dalam memahami konsep maupun menyelesaikan permasalahan yang disebabkan karena matematika terkesan monoton dan kurang kreatif pada proses pembelajarannya. Diantara penyebab matematika terkesan monoton dan kurang kreatif adalah penggunaan metode konvensional yang hanya memanfaatkan buku ajar pada saat guru mengajar (Maskur, Nofrizal, \& Syazali, 2017). Oleh karena itu untuk meminimalisir dampak negatif dari penggunan android dibutuhkan bahan ajar berbasis android yang dapat digunakan kapan saja dan dimana saja. Sehingga guru mampu melaksanakan perannya sebagai pendidik tidak hanya di ruang kelas tapi dimanapun dan kapanpun siswa menggunakan android.

Pramadana, Soro, dan Siswanto (2018) mengatakan bahwa sistem pembelajaran yang memanfaatkan sifat mobilitas dari perangkat smartphone, dapat memberikan suatu fungsi pembelajaran yang dilakukan dimanapun dan kapanpun. Yunendar (2016) menyatakan bahwa pembelajaran berbasis android dapat meningkatkan kemampuan belajar matematika siswa. Selain itu pembelajaran berbasis android yang bersifat interaktif dinilai efektif dalam meningkatkan pemahaman konsep matematika (Nurhairunnisa \& Sujarwo, 2017; Saidah \& Nugroho, 2015). Oleh karena itu android sangat berpotensi untuk dikembangkan menjadi bahan ajar matematika dan sarana pembelajaran pada android dapat mempermudah siswa dalam belajar.

Salah satu materi matematika yang perlu diperhatikan adalah materi perbandingan. Materi perbandingan ini selalu menjadi bagian dari soal UN pada siswa SMP. Selain itu materi perbandingan juga berkaitan dengan berbagai displin ilmu dan sering diterapkan dalam kehidupan sehari-hari. Salah satu bagian dari materi perbandingan adalah perbandingan berbalik nilai yaitu perbandingan yang perubahan nilai pada satu kuantitas diikuti oleh perubahan kuantitas lain dengan perubahan yang berlawanan (Lamon, 2006). 
Menurut Mulyono dan Hapizah (2018) seorang guru berperan penting dalam membentuk hasil belajar siswanya. Oleh karena itu guru perlu membentuk strategi dalam menyampaikan materi sehingga pembelajaran matematika tidak lagi terkesan monoton. Terlebih lagi materi pelajaran disampaikan dengan menggunakan metode konvensional dengan cara ceramah, tanya jawab dan penugasan dimana pada proses pembelajaran guru lebih dominan berperan dan siswa tidak begitu terlibat dalam pembelajaran. Hal ini berbalik dengan kurikulum 2013 yang dalam proses pembelajaran siswa memiliki peran utama atau student centere learning.

Berdasarkan hasil penelitian terdahulu menyatakan bahwa pembelajaran dengan menggunakan PBM memiliki efek potensial terhadap hasil belajar (Mulyono \& Hapizah 2018). PBM merupakan strategi belajar yang menggunakan masalah sebagai langkah awal dalam mengintegrasikan pengetahuan baru dimana siswa tidak lagi diberikan materi belajar seperti pada metode konvensional tapi siswa dituntut mengembangkan pengetahuannya secara mandiri (Dwiyanto \& Surur, 2016). Mulyono dan Hapizah (2018) menyatakan bahwa PBM merupakan model pembelajaran yang menyajikan masalah nyata sehingga dapat memicu siswa untuk belajar. Hal ini sejalan dengan materi perbandingan berbalik nilai yang berkaitan dengan masalah nyata dalam kehidupan sehari-hari sehingga dengan PBM dapat memicu siswa untuk belajar. PBM adalah inovasi yang paling signifikan dalam pendidikan (Boud \& Feletti, 1997). Oleh karena itu PBM dapat dijadikan sebagai solusi untuk mengatasi siswa yang kesulitan dalam belajar matematika dan salah satu strategi pembelajaran yang dapat dilakukan guru dalam menyampaikan konsep perbandingan berbalik nilai adalah penerapan model Pembelajaran Berbasis Masalah (PBM) dengan difasilitasi oleh bahan ajar berbasis android. Berdasarkan hal tersebut maka penting dilakukan suatu penelitian pengembangan bahan ajar perbandingan berbalik nilai berbasis Android Untuk Pembelajaran Siswa SMP Kelas VII.

\section{METODE PENELITIAN}

Penelitian ini merupakan penelitian pengembangan (development research). Produk yang dikembangkan pada penelitian ini adalah bahan ajar materi perbandingan berbalik nilai berbasis android untuk pembelajaran SMP kelas VII. Subjek ujicoba penelitian ini adalah siswa SMP N 1 Indralaya kelas VII dan kelas VIII. Objek penelitian ini adalah bahan ajar perbandingan berbalik nilai berbasis android yang ditinjau dari aspek validitas dan kepratisan. Tempat pelaksanaan penelitian dilakukan di SMP N 1 Indralaya yang beralamat Jl. Lintas Sumatra No. KM. 35. Indralaya Mulia Kec. Indralaya Kab. Ogan Ilir. Sumatera Selatan 30129. Model pengembangan yang digunakan pada penelitian ini adalah desain pembelajaran model ADDIE. ADDIE adalah singkatan dari Analysis, Design, Development, Implementation, and Evaluation. Untuk mengetahui kevalidan dan kepraktisan bahan ajar perbandingan berbalik nilai berbasis android untuk pembelajaran kelas VII, peneliti menggunakan beberapa teknik pengumpulan data yaitu walkthrough, angket, dan observasi. Teknik analisis data dilakukan sesuai dengan data yang terkumpul berdasarkan teknik pengumpulan data. Analisis data pada walkthrough dilakukan dengan menganalisis komentar dan saran yang diperoleh dari ahli materi dan ahli media terhadap bahan ajar yang telah dibuat. Sedangkan analisis data untuk lembar angket dan observasi dilakukan menggunakan kriteria kepraktisan dan skala Likert. Kategori kepraktisan tersebut dapat dilihat pada Tabel 1. 
Tabel 1. Kategori Kepraktisan Penggunaan Bahan

Ajar Perbandingan Berbalik Nilai Berbasis Android dimodifikasi dari Sugiyono (2013)

\begin{tabular}{ll}
\hline Nilai Persentase & Kriteria \\
\hline $84 \leq \mathrm{N}_{\mathrm{A}} \leq 100$ & Sangat Praktis \\
$68 \leq \mathrm{N}_{\mathrm{A}}<84$ & Praktis \\
$52 \leq \mathrm{N}_{\mathrm{A}}<68$ & Cukup Praktis \\
$36 \leq \mathrm{N}_{\mathrm{A}}<52$ & Tidak Praktis \\
$20 \leq \mathrm{N}_{\mathrm{A}}<36$ & Sangat Tidak Praktis \\
\hline
\end{tabular}

\section{HASIL DAN PEMBAHASAN}

Tahap Analisis. Pada tahap analisis, peneliti melakukan analisis terkait kebutuhan, kurikulum, dan siswa. Berdasarkan analisis kebutuhan diperoleh informasi bahwa bahan ajar yang digunakan di SMP Negeri 1 Indralaya telah memanfaatkan teknologi seperti proyektor namun dikarenakan persediaan proyketor terbatas maka guru lebih sering menggunakan LKPD dan buku paket. Peneliti juga mendapat informasi bahwa rata-rata siswa SMP telah memiliki smartphone dengan tipe android. Oleh karena itu peneliti menyimpulkan bahwa dibutuhkan bahan ajar berbasis android sebagai inovasi dalam proses pembelajaran. Berdasarkan analisis kurikulum peneliti memilih kompetensi dasar 3.8 dan 4.8 dengan materi perbandingan berbalik nilai. Analisis siswa diketahui bahwa siswa cenderung bosan dan tak jarang juga ada siswa yang mengantuk sehingga tertidur didalam kelas karena pelajarannya monoton.

Tahap Desain Merancang Permasalahan. Sebelum membuat produk bahan ajar, peneliti merancang permasalahan yang akan diangkat kedalam bahan ajar. Permasalahan yang dirancang merupakan permasalahan nyata dalam kehidupan sehari-hari yang penyelesaiannya sesuai dengan langkah-langkah dalam model pembelajaran berbasis masalah. Permasalahan yang telah dirancang dan disetujui oleh dosen pembimbing kemudian disajikan menjadi sebuah video animasi.

Tahap Desain Merancang Produk. Pada tahap ini peneliti membuat desain tampilan bahan ajar dengan menggunakan sketsa berupa kerangka isi bahan ajar dan storyboard. Kerangka isi bahan ajar memuat struktuk isi dalam bahan ajar yang meliputi (1) petunjuk penggunaan bahan ajar, (2) materi yang berisi petunjuk belajar, kompetensi yang harus dicapai, informasi pendukung untuk menjawab permasalahan, materi perbandingan berbalik nilai dan latihan, (3) kuis yang berisi soal pilihan ganda sebanyak 5 soal, dan (4) profil peneliti. Setelah menyusun kerangka isi bahan ajar selanjutnya peneliti menyusun storyboard. Tujuan penyusunan storyboard adalah untuk memberikan gambaran rancangan produk secara lebih jelas. Hasil rancangan storyboard dari beberapa menu dalam bahan ajar perbandingan berbalik nilai berbasis android diperlihatkan pada gambar 1 , gambar 2 , dan gambar 3.

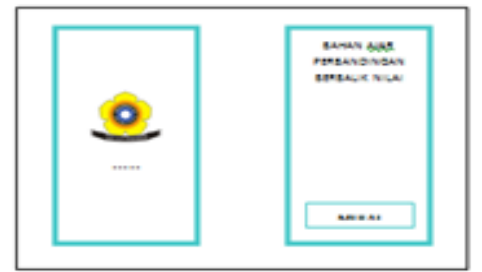

Gambar 1. Storyboard Halaman Loading dan Cover Bahan Ajar

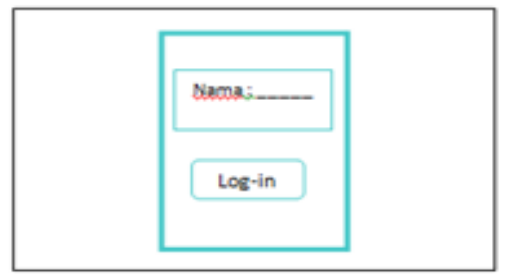

Gambar 2. Storyboard Halaman Log-in Bahan Ajar

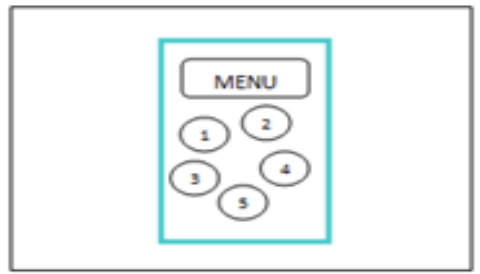

Gambar 3. Storyboard Halaman Menu Utama Bahan Ajar 
Gambar 1 adalah rancangan tampilan awal bahan ajar yaitu tampilan loading dan cover bahan ajar. Setelah tampilan awal pengguna akan menuju ke tampilan log-in yang dirancang seperti gambar 2. Pengguna harus mengisikan nama dan kelas pada halaman log-in agar dapat menuju ke menu utama. Tampilan menu utama bahan ajar disusun seperti gambar 3 . Pada menu utama terdapat 5 tombol yang bisa dipilih oleh pengguna, yaitu tombol petunjuk, materi, kuis, profil dan log-out.

Tahap Development Pembuatan Produk. Pada tahap ini, peneliti memproduksi bahan ajar perbandingan berbalik nilai. Dalam memproduksi bahan ajar ini peneliti memulai dengan mengetik isi dalam bahan ajar, pembuatan animasi dan pendesaianan tampilan background bahan ajar dengan menggunakan bantuan dari software adobe photoshop, camtasia dan Microsoft office powerpoint. Setelah itu dilanjutkan dengan memasukkan gambar, teks, suara, dan animasi yang telah dibuat kedalam bahan ajar menggunakan bantuan software Adobe Flash Professional Cs 6. Tampilan dari bahan ajar yang dikembangkan peneliti dapat dilihat pada Gambar 4., Gambar 5. dan Gambar 6.

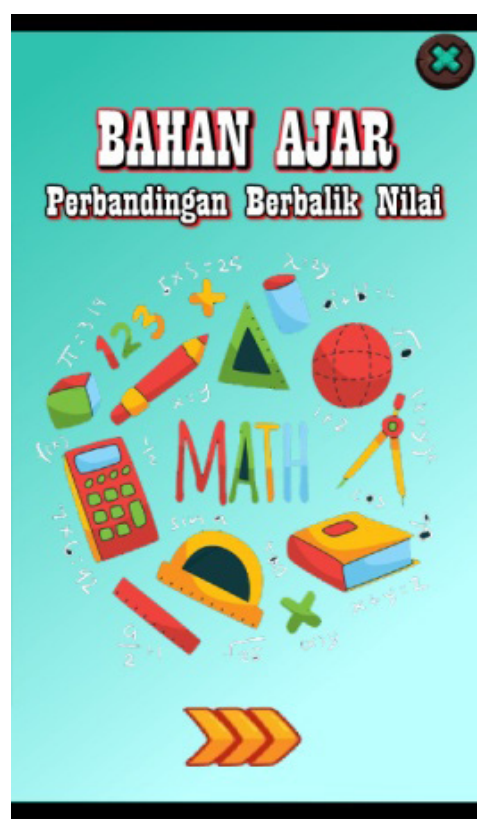

Gambar 4. Tampilan Cover Bahan Ajar.

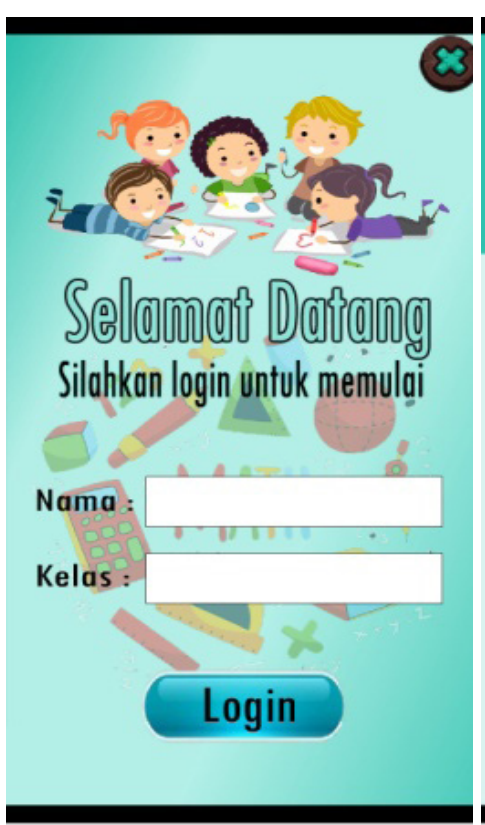

Gambar 5. Tampilan Log-in Bahan Ajar.

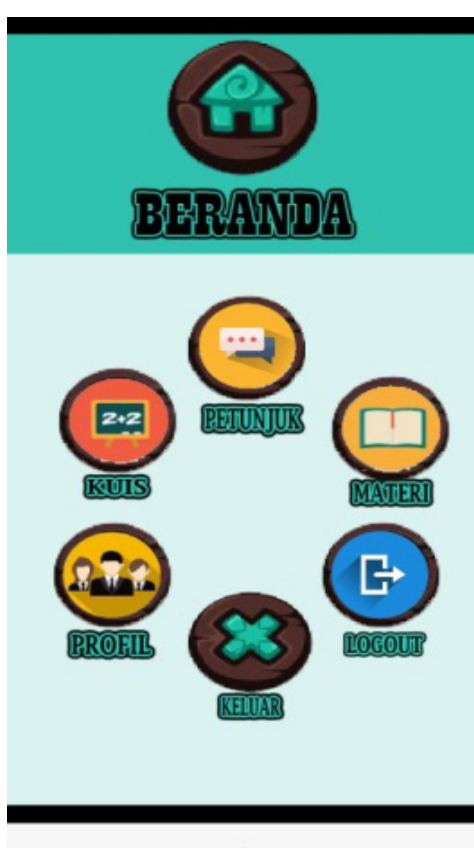

Gambar 6. Tampilan Menu Bahan Ajar.

Tahap Development Validasi Ahli. Bahan ajar yang telah dirancang kemudian divalidasi oleh 3 dosen pendidikan matematika FKIP Unsri yang terdiri dari ibu Elika Kurniadi S. Pd., M.Sc. Dan ibu Novita Sari S.Pd., M. Pd selaku validator ahli materi dan Bapak Budi Mulyono S.Pd., M.Sc. selaku validator ahli media untuk menentukan kelayakan bahan ajar yang dikembangkan dengan menilai serta memberikan komentar dan saran terhadap bahan ajar berdasarkan aspek isi, konstruk, dan bahasa. Hasil komentar dan saran dari ahli dapat dilihat pada tabel 2. 
Tabel 2 Hasil Komentar Validasi Ahli

\begin{tabular}{|c|c|}
\hline Aspek Penilaian & Komentar dan Saran \\
\hline Isi & $\begin{array}{l}\text { - Perbaiki definisi dan prinsip dari uraian materi. } \\
\text { - Perhatikan kembali indikator dan KD, gunakan kata } \\
\text { operasional pada indikator. } \\
\text { - Hindari screenshot untuk rumus dan beri penegasan } \\
\text { pada rumus. } \\
\text { - Tambahkan } 2 \text { soal lagi untuk soal latihan. }\end{array}$ \\
\hline Konstruk & $\begin{array}{l}\text { - Perbaiki kualitas gambar } \\
\text { - } \quad \text { Menbahkan waktu pada kuis } \\
\text { out atau keluar } \\
\text { - Warna tulisan dan background harus kontras dan } \\
\text { terbaca } \\
\text { - Tambaiknya ketika log-in tampilan naik keatas otomatis. } \\
\text { - Hilangkan tombata mulai pada tombol awal aplikasi } \\
\text { - }\end{array}$ \\
\hline Bahasa & $\begin{array}{l}\text { - Perhatikan kelogisan masalah dan perbaiki kalimat yang } \\
\text { rancu. } \\
\text { - Masih ada beberapa kata tidak sesuai EYD }\end{array}$ \\
\hline
\end{tabular}

Tahap Development Uji Coba Perorangan. Untuk mengetahui kevalidan bahan ajar, peneliti melakukan uji coba perorangan seiring dengan validasi ahli. Uji coba perorangan dilakukan kepada 6 siswa yang terdiri atas siswa kelas VII dan VIII SMP Negeri 1 Indralaya. Uji coba perorangan dilakukan untuk mendapatkan komentar dan saran siswa mengenai penggunaan bahan ajar perbandingan yang dikembangkan. Berdasarkan lembar komentar dan saran yang diisi oleh siswa terlihat sebagian besar siswa memberikan komentar yang positif mengenai bahan ajar. Dari 6 siswa yang menjadi subjek ujicoba diperoleh saran dari dua orang siswa untuk menambahkan penjelasan rumus serta perubahan tata letak tombol. Saran tersebut kemudian dipertimbangkan untuk perbaikan produk bahan ajar agar valid.

Tahap Development Revisi. Berdasarkan hasilvalidasi ahli dan uji coba perorangan, peneliti melakukan revisi bahan ajar perbandingan berbalik nilai dengan mempertimbangkan komentar dan saran yang telah diperoleh. Bahan ajar yang telah direvisi kemudian ditunjukkan kembali kepada validator. Selanjutnya validator menyatakan bahwa bahan ajar perbandingan berbalik nilai yang dikembangkan oleh peneliti telah dikategorikan valid dan sudah layak untuk diuji cobakan pada tahap kelompok kecil. Hasil revisi mengenai bahan ajar perbandingan berbalik nilai berbasis android berdasarkan validasi ahli dan uji coba perorangan disajikan pada Gambar 7, Gambar 8 dan Gambar 9.

Tahap Development Uji Coba Kelompok Kecil. Setelah bahan ajar perbandingan berbalik nilai berbasis android dinyatakan valid, dilakukan uji coba kelompok kecil untuk melihat kepraktisan bahan ajar. Kepraktisan bahan ajar dilihat dari hasil angket ] dan observasi pada saat uji coba kelompok kecil. Siswa yang menjadi subjek uji coba kelompok kecil merupakan siswa SMP N 1 Indralaya sebanyak 12 orang yang terdiri dari 6 siswa kelas VII dan 6 siswa kelas VIII. Siswa mengisi angket setelah menggunakan bahan ajar. Hasil analisis angket kepraktisan bahan ajar perbandingan berbalik nilai dapat dilihat pada tabel 3 dan hasil observasi yang dilakukan pada saat berlangsungnya uji coba kelompok kecil disajikan pada table 3 . 

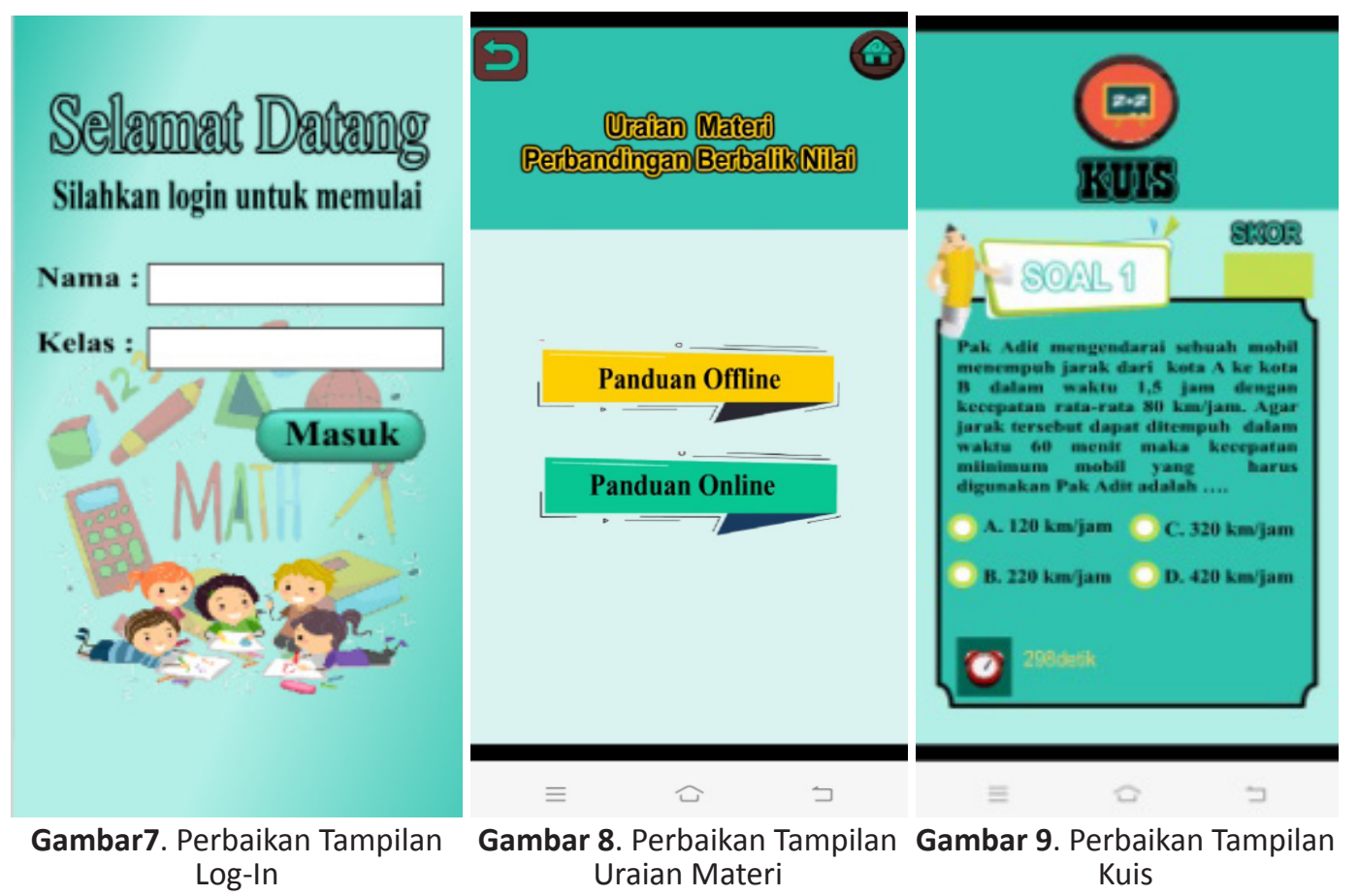

Gambar 8. Perbaikan Tampilan Gambar 9. Perbaikan Tampilan Uraian Materi Kuis

Tabel 3 Rekapitulasi Penilaian Angket terhadap Bahan Ajar Perbandingan Berbalik Nilai Berbasis Android Pada Uji Coba Kelompok Kecil

\begin{tabular}{llll}
\hline No & Aspek yang Dilihat & Persentase & Kriteria \\
\hline 1 & Kemenarikan bahan ajar & $86,33 \%$ & Sangat praktis \\
\hline 2 & Kejelasan materi pada bahan ajar & $81,83 \%$ & Praktis \\
\hline 3 & Kemudahan penggunaan bahan ajar & $74,17 \%$ & Praktis \\
\hline & Persentase Rata-rata & $82,17 \%$ & Praktis \\
\hline
\end{tabular}

Pada tabel 3 dapat dilihat hasil analisis nilai angket respon siswa secara keseluruhan diperoleh rata-rata persentase sebesar $82,17 \%$ dengan kriteria praktis. Kepraktisan dilihat dari aspek kemenarikan bahan ajar diperoleh persentase $86,33 \%$ yang menyatakan bahwa bahan ajar membuat siswa tertarik dan tidak bosan untuk belajar matematika menggunakan bahan ajar berbasis android yang disebabkan karena tampilan yang menarik dan pembelajaran yang menyenangkan. Sejalan dengan Hastuti, Waryanto, dan Retnowati (2017) yang menyatakan bahwa pembelajaran menggunakan multimedia seperti android berlangsung menyenangkan. Dilihat dari aspek kejelasan materi pada bahan ajar diperoleh persentase $81,83 \%$ menyatakan bahwa materi yang ada pada bahan ajar jelas hal ini disebabkan karena siswa menjawab setuju bahwa bahan ajar dapat memudahkan siswa dalam memahami materi. Selain itu siswa juga setuju bahwa siswa menjawab soal dengan baik setelah menggunakan bahan ajar senada dengan Setyadi (2017) bahwa android dapat memberikan manfaat bagi siswa untuk berlatih soal-soal matematika. Dilihat dari aspek kemudahan penggunaan bahan ajar dengan persentase $74,17 \%$ yang menyatakan bahwa sebagian besar siswa tidak mengalami kesulitan yang berarti pada saat menggunakan bahan ajar. Sehingga berdasarkan analisis data angket bahan ajar perbandingan berbalik nilaiberbasis android termasuk kedalam criteria praktis. 
Tabel 4. Rekapitulasi Penilaian Observasi terhadap Bahan Ajar Perbandingan Berbalik Nilai Berbasis Android Pada Uji Coba Kelompok Kecil

\begin{tabular}{llll}
\hline No & Aspek yang diobservasi & Persentase & Kriteria \\
\hline 1 & $\begin{array}{l}\text { Kemudahan siswa dalam menggunakan bahan ajar } \\
\text { perbandingan berbalik nilai. }\end{array}$ & $100 \%$ & Sangat mudah \\
\hline 2 & $\begin{array}{l}\text { Kemudahan siswa memahami konsep perbandingan } \\
\text { berbalik nilai menggunakan bahan ajar } \\
\text { perbandingan berbalik nilai. }\end{array}$ & $80 \%$ & Mudah \\
\hline 3 & $\begin{array}{l}\text { Timbal balik yang diberikan bahan ajar } \\
\text { perbandingan berbalik nilai kepada siswa melalui } \\
\text { Soal kuis. }\end{array}$ & $80 \%$ & Baik \\
\hline 4 & $\begin{array}{l}\text { Efisiensi waktu dalam penggunaan bahan ajar } \\
\text { perbandingan berbalik nilai. }\end{array}$ & $90 \%$ & Sangat baik \\
\hline 5 & $\begin{array}{l}\text { Interaktivitas siswa dalam menggunakan bahan ajar } \\
\text { perbandingan berbalik nilai. }\end{array}$ & $85 \%$ & Baik \\
\hline 6. & $\begin{array}{l}\text { Kemenarikan Tampilan bahan ajar perbandingan } \\
\text { berbalik nilai. }\end{array}$ & $100 \%$ & $\begin{array}{l}\text { Sangat } \\
\text { menarik }\end{array}$ \\
\hline Rata-Rata Persentase & $89,17 \%$ & Sangat Praktis \\
\hline
\end{tabular}

Kepraktisan bahan ajar juga diukur melalui hasil analisis data hasil observasi yang dilakukan selama berlangsungnya uji coba kelompok kecil. Dari hasil observasi diperoleh bahwa observer sangat setuju sebesar 100\% bahwa bahan ajar perbandingan berbalik nilai dapat digunakan dengan mudah oleh siswa dikarenakan tata letak tombol navigasi yang jelas dan adanya petunjuk penggunaan bahan ajar yang berisi fungsi-fungsi dari tombol yang ada pada bahan ajar. Hal ini menunjukkan bahwa kemudahan penggunaan bahan ajar dalam kriteria sangat mudah. Observer setuju sebesar $80 \%$ bahwa bahan ajar perbandingan berbalik nilai memberi siswa kemudahan untuk menjelaskan konsep perbandingan berbalik nilai hal ini ditunjukkan pada saat akhir uji coba siswa diminta untuk menjelaskan apa definisi dari perbandingan berbalik nilai. Artinya dengan menggunakan bahan ajar $80 \%$ siswa menjadi mudah dalam memahami materi. Observer setuju sebesar $80 \%$ bahwa bahan ajar memberikan timbal balik yang baik kepada siswa melalui soal kuis dikarenakan munculnya gambar dan suara benar ketika siswa memilih jawaban yang benar dan muncul gambar dan suara salah ketika siswa menjawab salah. Observer $90 \%$ sangat setuju bahan ajar perbandingan berbalik nilai membutuhkan waktu yang singkat dalam penggunaannya dikarenakan siswa tidak merasa bingung saat menggunakan bahan ajar sehingga bahan ajar memiliki efisiensi waktu yang sangat baik. Observer $85 \%$ sangat setuju bahwa bahan ajar perbandingan berbalik nilai memfasilitasi terjadinya interaktifitas siswa dalam menggunakannya karena siswa dapat mengoperasikan bahan ajar secara langsung. Observer $100 \%$ setuju bahwa tampilan bahan ajar menyebabkan siswa tertarik untuk belajar materi perbandingan berbalik nilai dikarenakan tampilan bahan ajar yang berbeda dengan buku serta adanya kuis yang membuat siswa tertarik untuk mengerjakannya. Halhal tersebut Sejalan dengan Komariah, Suhendri, dan Hakim (2018) bahwa kelebihan bahan ajar berbasis android adalah materi yang dikemas secara singkat dan menarik dengan disajikan slide pembelajaran interaktif yang berwarna sehingga membuat siswa lebih antusias, bersemangat, dan dapat memahami isi materi dengan cepat sehingga waktu yang dibutuhkan menjadi lebih singkat. 


\section{SIMPULAN DAN SARAN}

Berdasarkan hasil penelitian dan analisis data yang telah dilakukan, dapat disimpulkan bahwa bahan ajar perbandingan berbalik nilai berbasis Android untuk pembelajaran SMP kelas VII yang dikembangkan peneliti telah sesuai dengan karakteristik yang dikategorikan valid dan praktis. Dinyatakan valid berdasarkan hasil penilaian validator terhadap aspek isi, konstruk dan bahasa dalam bahan ajar dan dinyatakan praktis berdasarkan persentase data hasil observasi dan angket yang memperoleh nilai sebesar 89,17\% dengan kriteria sangat praktis dan $82,17 \%$ dengan kriteria praktis. Saran untuk penelitian selanjutnya diharapkan dilakukan penelitian pengembangan pada materi lain sehingga menambah bahan pembelajaran yang bisa digunakan oleh siswa khusunya siswa SMP.

\section{DAFTAR RUJUKAN}

APJII. (2015). Indonesia Internet Users. Laporan Asosiasi Penyelenggaraan Jasa Internet. Retrieved from Http://Www.APJII.Or.Id

Boud, D., \& Feletti, G.I. (1997) Changing Problem Based Learning. Introduction to the Second Edition. In: Boud, D. and Felleti, G.I., Eds., The Challenge of Problembase Learning, 2nd Edition, Kogan Page, London, 114.

Dwiyanto, F., \& Surur, M. (2016). Strategi Pembelajaran Berbasis Masalah. Surabaya, Indonesia: Garuda Mas Sejahtera.

Mulyono, B., \& Hapizah. (2018). Pemahaman Konsep Dalam Pembelajaran Matematika. Kalamatika Jurnal Pendidikan Matematika, 3(2), 103-122. DOI: 10.22236/ KALAMATIKA.vol3no2.2018

Hastuti, N.L., Waryanto, N.H., \& Retnowati, E. (2017). Pengembangan Media Pembelajaran Matematika Berbasis Edutainment Berupa Android Mobile Game Untuk Siswa Smp Kelas VII Pada Materi Segi Empat. Jurnal Pendidikan Matematika - S1, 6(2), 67-75. Retrieved from http://journal.student.uny.ac.id/ojs/index.php/pmath/

Komariah, S., Suhendri, H., \& Hakim, A.R. (2018). Pengembangan Media Pembelajaran Matematika Siswa Smp Berbasis Android.JKPM (Jurnal Kajian Pendidikan Matematika), 4 (1), 43-52. DOI: $10.30998 / \mathrm{ikpm} . \mathrm{v} 4 \mathrm{i1} 1.2805$

Lamon, S. J. (2006). Teaching Fractions And Ratios For Understanding : Essential Content Knowledge And Instructional Strategies For Teachers 2nd Ed. Lawrence Erlbaum Associates.

Maskur, R., Nofrizal, \& Syazali, M. (2017). Pengembangan Media Pembelajaran Matematika Dengan Macromedia Flash. Al-Jabar : Jurnal Pendidikan Matematika, 8(2), 177-186. DOI: $10.24042 /$ ajpm.v8i2.2014

Novalius, F. (2018). Indonesia Pengguna Smartphone Ke-4 Dunia, Begini Tekad Menperin Dongkrak Industri Telematika. Retrieved from: Okezon.Com.

Nurhairunnisah, \& Sujarwo. (2018). Bahan ajar interaktif untuk meningkatkan pemahaman konsep Matematika pada siswa SMA kelas X. Jurnal Inovasi Teknologi Pendidikan, 5(2), 192-203. DOI: $10.21831 /$ jitp.v5i2.15320

Pramadana, T.I., Soro, S., \& Siswanto, R.D. (2018). Pengembangan Aplikasi Bangun Datar Sederhana (Bandara) Matematika Berbasis Android Pada Materi Bangun Datar sederhana Di Tingkat SMP. Prosiding Seminar Nasional Teknoka ke - 3, 3, I13-I16. DOI: 10.22236/teknoka.v3i0.2894

Widadi, S.Y., \& Pramudita, I. A. (2018). Gambaran Motivasi Belajar Pada Siswa Pengguna Smartphone Di Smp Negeri 4 Garut. Jurnal Keperawatan Silampari, 2(1), 203-206. DOI: $10.31539 / \mathrm{jks} . v 2 \mathrm{i} 1.304$ 
Saidah, I. N., \& Nugroho, M. A. (2015). Pengembangan Media Pembelajaran Berbentuk Permainan Edukasi Akuntansi Cari Kata (Acak) Menggunakan Adobe Flash Cs5. Jurnal Pendidikan Akuntansi Indonesia, 13(1), 65-74. DOI: 10.21831/jpai.v13i1.5190

Schwab, K. (2016). The Fourth Industrial Revolution. Switzerland: World Economic Forum.

Setyadi, D. (2017). Pengembangan mobile learning berbasis android sebagai sarana berlatih mengerjakan soal matematika. Satya Widya, 33(2), 87-92. DOI: 10.24246/j.sw.2017. v33.i2.p87-92

Statista. (2019). Smartphone Users Worldwide 2014-2020. Retrieved from: Www.Statista. Com.

Sugiyono. (2013). Metode Penelitian Kuantitatif Kualitatif Dan R\&D. Bandung, Indonesia: CV. Alfabeta.

Yunendar, W. (2016). Pengembangan Modul Pembelajaran Berbasis Smartphone (Android) Pada Mata Pelajaran Teknologi Informasi Dan Komunikasi Di SMA Negeri 2 Makassar. Skripsi. Universitas Negeri Makassar. Retrieved from: http://eprints.unm.ac.id/id/ eprint/6482

Yuni, R.S.P., \& Pierewan, A.C. (2017). Hubungan intensitas penggunaan smartphone dengan disiplin belajar siswa. E-Societas, 6(1), 1-16. Retrieved from: http://journal.student. uny.ac.id/ojs/index.php/societas/ 